\section{Required Reading For}
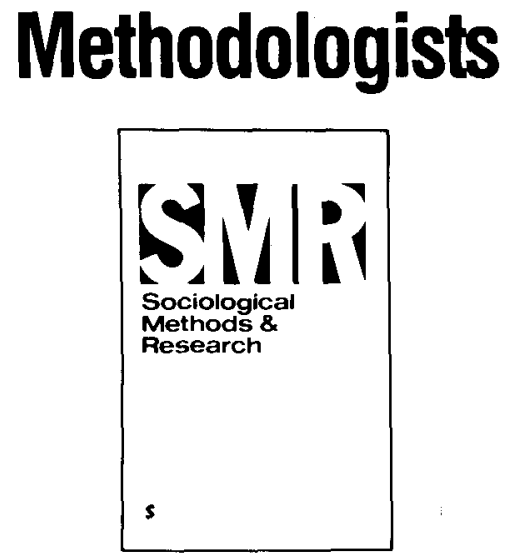

\section{A leading journal of quantitative research and methodology}

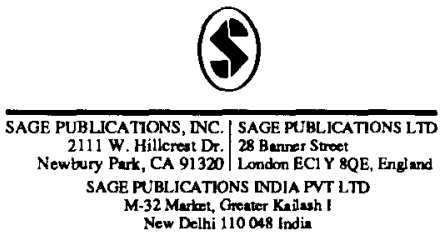

\section{SMR/Sociological Methods \& Research}

\section{Editor: J. Scott Long, Indiana University}

Devoted to the advancement of social and behavioral science methodology, SMR/Sociological Methods \& Research emphasizes articles that clarify methodological problems, or that assist in organizing the known facts in a particular discipline or research area.

Empirically-based, SMR/Sociological Methods \& Research strives to assess the validity, effectiveness and theoretical significance of the empirical research methods used in social science methodology. Though its articles are highly focused, the journal addresses a wide range of subject areas: sociology, psychology, political science, economics, anthropology, education research are just a few.

Featuring articles on such topics as:

- Simultaneous Latent Structure Analysis

- Principal Components Analysis

- Organizational Behavior Research

- Regression Analysis

\section{FREQUENCY:}

Quarterly in August, November, February, May

$\begin{array}{lcc}\text { Rates: } & \text { One Year } & \text { Two Years } \\ \text { Individual } & \$ 36.00 & \$ 108.00 \\ \text { Institutional } & \$ 99.00 & \$ 297.00\end{array}$




\section{JOURNAL OF \\ American Ethnic \\ History}

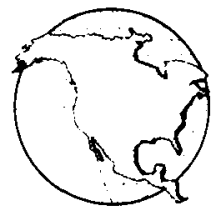

\section{JOURNAL OF \\ American Ethnic History}

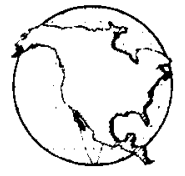

Spring 1987

Volume 6. Number 2

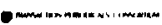

Ronald H. Bayor, editor

(Georgia Institute of Technology)

Addresses various aspects of American immigration and ethnic history, including background of emigration, ethnic and racial groups, native Americans, immigration policies, and the processes of acculturation.

\section{Recent articles Include:}

Alfred Erlch Senn and Alfonsas Eldintas on Lithuanian immigrants in America and the Lithuanian national movement before 1914. Howard Gilletie, Jr. and Alan M. Kraut discuss the evolution of Washington's Italian-American community from 1890-World War It.

George Anthony Peffer studies the emigration experiences of Chinese women under the Page Law, 1875-1882.

Sydney StahI Weinberg examines Jewish mothers and immigrant daughters as positive and negative role models.

Publlshed Semiannually

The offliclal journal

of the Immigration History Sociely.

Subscription rates: "*

Individuals: $\$ 17 / y r ; \$ 34 / 2 y r s ; \$ 47 / 3 y r s$

Institutions: $\$ 32 / y r ; \$ 64 / 2 y r s ; \$ 91 / 3 y r s$.

Domestic first-class mall add $\$ 12 / y r$.

Forelgn surface mall add $\$ 12 / \mathrm{yr}$.

Foreign alrmall add $\$ 25 / y r$.

* Includes membership in the Immigration History Society and semiannual Immigration History Newsletter. 
EDITOR

Eric Monkkonen, University of California, Los Angeles

ASSOCIATE EDITOR

Robert P. Swierenga, Kent State University

BOARD OF EDITORS

Barbara Anderson, University of Michigan

William O. Aydelotte, University of Iowa

Lee Benson, University of Pennsylvania

Allan G. Bogue, University of Wisconsin

William Clagett, Florida State University

Ellen Dwyer, Indiana University

Heinz Eulau, Stanford University

Roderick Floud, University of London

David W. Galenson, University of Chicago

Alice Goldstein, Brown University

Myron P. Gutmann, University of Texas at Austin

David I. Kertzer, Bowdoin College

J. Morgan Kousser, California Institute of Technology

Robert C. Liebman, Portland State University

Terrence McDonald, University of Michigan

Patrick Manning, Northeastern University

Warren Miller, Arizona State University

Leslie Moch, University of Michigan, Flint

Karen Orren, University of California, Los Angeles

John Padgett, University of Chicago

Donald Parkerson, East Carolina University

Richard Steckel, Ohio State University

John J. TePaske, Duke University

Susan Cott Watkins, University of Pennsylvania

Ian Winchester, Ontario Institute for Studies in Education

SSHA EXECUTIVE DIRECTOR

Howard W. Allen, Southern Illinois University

EDITORIal assistant Matthew C. Lee 

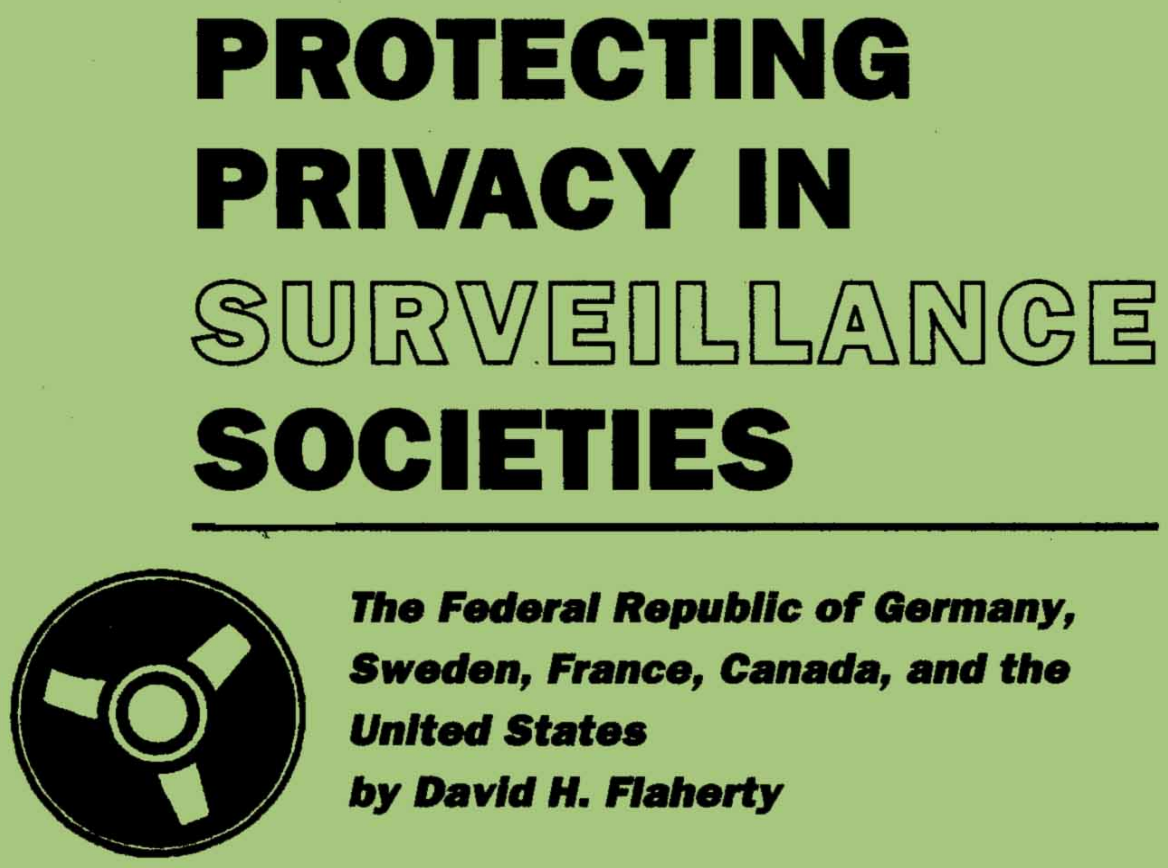

In this first work on privacy and data protection from a crossnational perspective, David Flaherty establishes the topic as a field of scholarly inquiry in terms of public policy, law, and public administration. Drawing from research derived primarily from interviews, Flaherty offers a comparative and critical analysis of what data protectors are actually doing to preserve individual rights and what problems they are encountering. "I enthusiastically recommend the book to legislators, policymakers, scholars, and concerned citizens throughout the world."-U.S. Congressman Glenn English, former chairman of the Government Information, Justice, and Agriculture Subcommittee 507 pp., $\$ 45$

available at bookstores or from

\section{THE UNIVERSITY OF NORTH CAROLINA PRESS}

Post Office Box 2288 / Chapel Hill, NC 27515-2288

Toll-free orders: $1-800-848-6224$ 